\title{
Interrelations between the Urban Wage Premium and Firm-Size Wage Differentials A Microdata Cohort Analysis for Germany
}

\author{
Florian LEHMER \\ Joachim MÖLLER \# \\ Department of Economics, University of Regensburg \\ Universitätsstraße 31, D-93053 Regensburg, Germany \\ University of Regensburg \\ November 2006
}

\begin{abstract}
At the interface of regional and labor economics, our paper deals with two central topics in the analysis of wage formation, the urban wage premium and the firm-size earnings differential. Choosing a cohort of workers from a large panel micro data set, we get an urban wage premium of 8 percent and a large firm premium of 11 percent. We find that large firms play a crucial role for explaining the higher productivity in urban areas. The wage growth in urban areas is not tied to the firm level. Hence our findings confirm the view that externalities are operating in the urban environment and not only within the firms.
\end{abstract}

\section{Keywords:}

Urban wage premium, firm-size earnings differential, urban- rural migration, firm-size mobility, wage growth, externalities.

JEL-classification: J61, R23

\footnotetext{
\# Correspondence to: Prof. Dr. Joachim Möller, Department of Economics, University of Regensburg, Universitätsstraße 31, D-93053 Regensburg, Germany, e-mail: joachim.moeller@wiwi.uni-regensburg.de, phone: +49 (941) 943-2550, fax: +49 (941) 943-2735. Financial support from the German Science Foundation (Deutsche Forschungsgemeinschaft, Projekt MO 523/3-2) is gratefully acknowledged.
} 


\section{Introduction}

At the interface of regional and labor economics, our paper deals with two central topics in the analysis of wage formation, the urban wage premium and the firm-size wage differential. The phenomenon of workers being better paid in agglomerations is an old theme in regional economics which dates back to Marshall (1890) and others. Recently, in the light of new micro data and modern econometric methods, several authors have taken a fresh look at the empirical evidence. In an important study for the U.S., for instance, Glaeser, Maré (2001) found that city workers are paid 33 percent more than in rural areas. Since the higher pay must be related to higher productivity, regional economists basically offer two alternative explanations for this observable fact. Either higher wages in agglomerations are a consequence of a selection mechanism which attracts the most able workers to cities, or it is the city environment that makes workers more productive. In the latter case, an equilibrating mechanism in the spirit of Harris and Todaro (1970) is required to hinder workers from flocking into urban areas because of the high wage. Agglomeration disadvantages include problems such as congestion, pollution and higher costs for non-tradables, in particular housing services.

As a matter of fact, empirical studies typically find a strong and statistically significant positive relationship between density measures of economic activity and productivity [e.g. Ciccone and Hall (1996), Harris and Ioannides (2000), Ciccone (2002)]. ${ }^{1}$ Several "conventional" explanations can be given for this. Firstly, agglomerations provide specific advantages to firms because of their infrastructure and the access to other public goods they offer. Secondly, the sheer size of the labor market in cities leads to better matches between the worker and the work place ${ }^{2}$. Thirdly, the concentration of purchasing power in agglomerations causes higher demand. The New Economic Geography (NEG, see Fujita, Krugman, Venables (1999)) contributes the following further arguments. The NEG theory stresses the interactions of increasing returns, transportation costs and market or demand effects. The advantages of clustering of firms arise because of the proximity of suppliers of intermediate goods, among others. There are two sources of cost reduction in supply-chain clusters.

\footnotetext{
${ }^{1}$ Previous studies focus on the positive effects of city population or industry employment on productivity (e.g Sveikauskas (1975), Segal (1976), Moomaw (1981, 1985) and Henderson (1986).

${ }^{2}$ See Wheeler (2001) for a formal model.
} 
On the one hand, a higher number of "upstream" firms imply the availability of a greater variety of intermediate goods for a given firm $F$ within the chain thereby increasing its productivity. On the other hand, a higher number of "downstream" firms boosts the demand for the goods it produces thereby lowering its unit costs because of scale effects. As a result, clustering leads to higher productivity of workers and hence higher wages. A further important line of argument is that agglomeration fosters knowledge spillovers between workers. Living in cities makes workers more productive because social interactions speed up the accumulation of human capital. Such human capital externalities are object of a voluminous literature [e.g. Moretti (2004), Rosenthal, Strange (2005), Rauch (1993), Lucas (2001)]. Despite the overwhelming evidence on the existence of human capital externalities, almost nothing is known whether human capital externalities are operating on the firm level or in the urban environment.

Concerning the selection hypothesis: Why should firms in agglomerations be pickier in recruiting their workers? One line of argument is that the agglomeration specifically attracts firms engaged in intensive research and development activities. These firms tend to profit from knowledge spillovers. If especially the most able workers are likely to increase their productivity by knowledge spillovers, it might pay out for the firm to establish sharper selection criteria for recruitment. A related hypothesis is based on a sorting argument: the more able workers are more likely to be attracted by cities. The study of Combes, Duranton, Gobillon (2003) states that this is the case for France where the bulk of interregional wage disparities is due to a geographically uneven distribution of skills. One reason for this could be that the more able workers anticipate the knowledge spillovers in the cities which could accelerate the process of human capital formation. ${ }^{3}$ A second reason for the attractiveness of cities might be their amenities (possibilities of consumption, cultural activities), which cater those with high incomes. ${ }^{4}$ As Glaeser and Maré (2001: 318) point out, the ability hypothesis implies that an urban wage premium exists, even after controlling for the local price level.

\footnotetext{
3 See Peri (2001) for a formal model.

${ }^{4}$ Adamson, Clark and Partridge (2004) state that skilled workers are more influenced by urban amenities than by urban productivity.
} 
Empirically, there is strong support for the existence of an urban wage premium for observationally equivalent workers. ${ }^{5}$ Using panel data methods it is possible to exclude unobserved heterogeneity of workers to explain the urban wage premium. Controlling for the local price level, however, turns out to be difficult because reliable data does not exist.

We now turn to the firm-size wage premium. Brown et al. (1990) report that hourly wages of workers in large firms are 35 percent higher than in small firms. Oi, Idson (1999) distinguish between behavioral explanations and a productivity hypothesis. The former are: (1) big firms decrease the costs of monitoring through matching of productive workers; (2) the likelihood of shirking is higher than in small firms and therefore large establishments have to pay efficiency wages and (3) big firms are more able to share rents because of greater market power and lower prices for non-labor inputs, among others. Furthermore, the so-called productivity hypothesis states that the required performance standards are higher in big firms which have to be compensated by higher wages and that more productive employees are needed to operate high- technology machines ${ }^{6}$. Brown, Medoff (1997) additionally points to the fact that large firms are also old firms which have higher survival rates. Therefore they invest more in training which results in more productive workers. ${ }^{7}$

There are several similarities in the explanation of the urban and the firm size wage differential. In both cases one can distinguish between hypotheses being related to productivity or ability. One can consider the large firm as an organizer of the value chain using internal and external sources. The large firm is able to internalize some of the advantages arising from backward and forward linkages already described in the context of localization and urbanization economics. From this point of view one can argue that the large firm benefits more from agglomeration. Empirically it is a striking fact that the average firm size is significantly higher in dense regions. Hence the urban wage premium might at least to some extent be interrelated with firm size. To the best of our knowledge there exists no study combining these two aspects although both phenomena are well investigated separately.

\footnotetext{
5 Beside Glaeser and Maré (2001) a number of studies find that firms in dense areas pay more for equivalent workers than in rural areas. See, for instance, Rosenthal and Strange (2005) and Wheeler (2001) for the U.S., Haas and Möller (2004) for West Germany, Combes, Duranton and Gobillon (2003) for France, Di Addario and Pattacchini (2004) for Italy and Tabuchi and Yoshida (2000) for Japan. Moreover, for the U.S., Diamond and Simon (1990) and Wheaton and Lewis (2002) identify strong gains to specialization in urban areas.

6 The increased capital/ labor ratio leads to an advanced adoption of new technologies.

7 An alternative survey of possible explanations for the size- wage premium is given by Troske (1999).
} 
The aim of our paper is to analyze how the urban wage premium is affected by taking into account that workers in large firms are clearly over-represented in agglomerated areas. Our method is to observe a cohort of workers over time and to study the effect of migration on the one hand and changing the firm size on the other. We then follow the approach of Glaeser, Maré (2001) insofar as we examine the development of wage patterns of rural-urban and urban-rural movers and ask whether the urban wage premium accrues over time and whether the premium persists if workers leave cities. It turns out to be of crucial importance not only to consider regional mobility, but also to shed light into the "black box" of firm-size mobility. This allows us to identify whether the urban premium primarily develops within or outside the firm.

The remainder of the paper is organized as follows: The next section deals with a description of our data source, methodological issues, basic definitions and descriptive evidence. Section 3 introduces our econometric model and presents the results. Section 4 concludes.

\section{Data, basic definitions and some descriptive evidence}

\subsection{Data}

The data used in this paper is a one percent random sample from the Employment Statistics of the Institute of Employment Research, Nuremberg (IABREG) ${ }^{8}$ It includes all workers, employees and trainees with the obligation of paying social insurance contributions. Not included in the data are selfemployed persons, civil servants, marginal employed persons and students enrolled in higher education. The employment register contains detailed histories for each worker's time in employment. Here we consider all persons aged 16 to 70 years who were employed on $30^{\text {th }}$ June of each year. The key variable for our analysis is gross daily wages ${ }^{9}$ being gathered in the register for administrative purposes. Due to legal sanctions for the employer in cases of misreporting, the variable can be considered highly reliable. Because of the contribution assessment ceiling in the German social

\footnotetext{
${ }^{8}$ For a description of the data source please see Bender, Haas (2002).

9 The notions wages and earnings are used synonymously throughout this paper. Daily gross earnings are calculated as average over the observed employment period for each person.
} 
security system, however, the earnings information is top coded. This concerns less than 10 percent of all observations. The likelihood of censoring increases with age and education. Moreover, the data set gives information on personal characteristics of workers like gender, age and education as well as some basic information about the employer (industry affiliation, location, firm size).

The qualification of the considered workers can be subdivided into three categories: (i) low-skilled: persons with no occupational qualification regardless of which schooling level, that means with or without upper secondary education (Abitur); (ii) skilled: persons with an occupational qualification whether they have an upper secondary education (Abitur) or not; (iii) high-skilled: persons with upper secondary education who are holding a degree for university or polytechnics type of higher education.

The data contains regional information which refers to the location of the firm respectively the work place and not the residence of a worker. In order to distinguish between urban and rural areas we use a classification scheme of the Bundesanstalt für Bauwesen und Raumordnung (BBR) that differentiates between nine types of regions according to centrality and population density. At NUTS3 (county) level the classification "urban" collects metropolitan core cities (BBR1) and highly urbanized districts in areas with large agglomerations (BBR2) as well as central cities in regions with intermediate agglomerations (BBR5) as urban areas. All other regions are classified as rural (see appendix, table A1). The data also includes information about firm size which is crucial for our purpose. In the following we differentiate between small firms (1-500 workers) and large firms with more than 500 workers.

Because there are still large structural differences in labor market and migration patterns between the eastern and the western part of Germany we constrict the analysis to workers in West Germany. We exclude part-time workers, workers, those in an apprenticeship or with more than one employment contract. Moreover, we drop all observations with no valid information on earnings, age, skills or the region of the workplace (see appendix, table A2 for data selection). 


\subsection{Basic definitions and methods}

In order to identify the urban wage premium and the firm size earnings differential in the panel data analysis later on, we investigate different aspects of mobility. First of all, mobility of an employed worker is related to the change of the firm, where he or she is occupied. Thereby the worker can choose an employer of either the same or a different firm-size category compared to the previous one. Therefore, a second aspect of workers' mobility concerns a change in the firm-size category of the employer. Thirdly, mobility can have a spatial dimension as well, since it may require a change in the region where the workplace is located of employees and/ or where the person lives. Here we concentrate on the former. Therefore we define regional mobility of employed workers as a change in the region where the workplace is located.

Basically we are interested in wage growth effects accruing from changing the firm, the firm-size category and/ or the region, respectively. ${ }^{10}$ To this aim, we analyze a cohort of workers. We first selected all workers in the data base who were employed at the cut-off date in all years from 1990 to 1997. Based on the observations for the two consecutive years 1990 and 1991, we divided the group into stayers and movers with respect to the three dimensions of worker's mobility as defined above. ${ }^{11}$ The cohort consists of all employed workers who where possibly mobile between 1990 and 1991 but stayed with the same employer from 1992 onwards, hence not only persons with unemployment spells but also multiple movers were disregarded. As a consequence, we obtain a balanced panel for a cohort for which the selectivity problem is markedly reduced.

Table 1 gives some basic information on the number of observations for movers and stayers in our sample. In total, we have 58,112 persons in the cohort. Within the total, 3,666, or 6.3 percent, firm movers can be identified. In two thirds of all cases, inter-firm mobility takes place within the small firm-size category (2,353 observations). The number of workers moving between large firms is 400 . The group of firm-size movers comprises 913 persons whereof the majority (555 individuals) moves from small firms to large ones. The group of firm movers who additionally changed the region of the

\footnotetext{
${ }^{10}$ We do not consider inter-regional mobility within the same firm, i.e. between different operating sites of the same firm. This aspect of workers' mobility has been investigated by Hunt (2004).

11 Throughout the paper we concentrate on a cohort starting in 1990/ 91. All documented results are fairly similar for other cohorts starting in the years $1985 / 86$ to 1989/90. These results are not documented here and are available from the authors on request.
} 
workplace consists of 1,478 workers ( 2.5 percent). In the sample we have 268 workers changing their workplace from rural to urban areas and 251 movers in the opposite direction. Hence a small net inflow of mobile workers into cities can be observed at the beginning of the nineties.

\subsection{Firm size and region types: Some descriptive evidence}

Table 2 shows that 58 percent (33,689 individuals) of all workers in the cohort are employed in urban areas. The share of workers with urban status in small versus large firms is 56 to 44 percent. The distribution across the two firm-size categories is markedly different in rural areas: Here more than three out of four workers (77 percent) are employed in the small firm-size category. This implies that in rural areas the share of workers in large firms is only half its size in urban areas. Hence workers with urban status are much more likely to work in larger firms than their counterparts outside the cities.

Table 3 examines differences in the average skill levels of male and female workers in urban and rural areas. According to the human capital literature [e.g. Moretti (2004)], skill intensity should be higher in agglomerations. This is clearly confirmed by the evidence here, as in our cohort the share of highskilled male and female employees in cities is more than double its value in rural areas. ${ }^{12}$ Most interestingly, however, the share of low-skilled male workers in both types of regions turns out to be more or less comparable. Differences are found with respect to the intermediate skill category. Male workers of this category are under-represented in cities while their female counterpart is overrepresented.

Comparing the same categories across small and large firms yields the results shown in table 4. For both gender, we see that the shares of low-skilled and high-skilled workers in larger firms exceed those in smaller firms. The intermediate skill category, however, is clearly under-represented in larger firms. In relative terms, the differences in the skill composition of the workforce are especially pronounced for the high-skilled. Compared to smaller firms, the share of this skill category is more

\footnotetext{
12 Note that only employees with no interruptions in their employment spells were selected here. Since female workers typically exhibit more unstable employment patterns, the females are somewhat underrepresented in the sample.
} 
than twice as high in larger firms. Moreover, we see that female workers tend to be less skilled and that low-skilled females are markedly over-represented in large firms.

To summarize the descriptive evidence: High-skilled workers are more concentrated in both urban areas and large firms, while the intermediate skill category tends be relatively more frequent in rural areas and small firms. How wage differentials between specific groups of workers can be traced back to the uneven spatial distribution will be investigated in the next section.

\section{Econometric estimates: the urban wage premium and the firm size earnings differential}

\subsection{Outline of the estimation approach}

In order to determine the urban wage premium we estimate three variants of a Mincer-type wage equation. ${ }^{13}$ More specifically, our first estimation approach assumes a linear relationship between log earnings and several explanatory variables measuring skill/ gender and (potential) experience effects. The workers' potential on-the job experience $(E X P)$ is measured in years as age minus average duration of education minus six. ${ }^{14}$ Potential experience enters the wage equation in linear and quadratic form to model the typical non-linear (concave) wage/ experience profile. We measure the effect of six skill/ gender categories by corresponding $(0,1)$-dummy variables, where $D$-SKILL $L_{n}(n=1, \ldots, 3)$ indicate male workers with low, intermediate and high skills, respectively, while $D$-SKILL $L_{n}(n=4, \ldots, 6)$ stand for the corresponding three skill categories of female workers. In addition, our estimation approach includes interaction effects between the workers' experience with gender and qualification ${ }^{15}$. Finally, we introduce a separate $(0,1)$-dummy variable for the urban status $(D-U R B)$. Suppressing the time index, the equation to be estimated is hence given as

\footnotetext{
13 See Mincer (1974).

14 For low-skilled workers without an upper secondary education we impose 10 years as average time of education, for low-skilled workers with an upper secondary education 13 years, for skilled workers 12.5 and 15 years, respectively, for high-skilled workers holding a degree from a polytechnics type of higher education 16 years and for high-skilled university alumni 18 years.

${ }^{15}$ All workers except for low-skilled male and female workers are considered as qualified. All interactions with experience are defined for the linear and quadratic experience variable.
} 


$$
\begin{aligned}
\ln w_{i}= & \alpha_{0}+\alpha_{1} \operatorname{EXP}_{i}+\alpha_{2} \operatorname{EXP}_{i}^{2}+\sum_{n=2}^{6} \alpha_{3, n} D-\operatorname{SKILL}_{n, i}+\alpha_{4} D-U R B_{i} \\
& + \text { interactions of experience and experience squared } \\
& \text { with gender and qualification }+u_{i} .
\end{aligned}
$$

The dependent variable $w_{i}$ stands for (daily) earnings of individual $i$. The error term $u_{i}$ is assumed to be identically and independently distributed. To account for top coding in the data, we use the Tobit estimation method.

In order to control for the fact that the urban wage premium and the firm size wage differential might be interrelated, we additionally include the term

$$
\ldots+\alpha_{5} D-L F S I Z E_{i} \ldots
$$

in the estimation approach described above, where D-LFSIZE indicates a $(0,1)$-dummy variable for the large firm-size category. The third variant of the wage equation additionally uses a bulk of industry dummies because one can reasonably suspect a sizeable impact of industry structure on wages. ${ }^{16}$ Hence, the ancillary term is

$$
\ldots+\sum_{\mathrm{k}=2}^{36} \alpha_{6, k} D-I N D_{k, i} \cdots
$$

where $D$-IND $D_{k}$ stands for a $(0,1)$-dummy variable taking the value of unity if an individual belongs to industry $k$ and zero elsewhere.

\subsection{Estimation results}

Table 5 contains the results of the Tobit estimates for the year 1997. The number of observations is 58,112 whereof 8,299 observations or roughly 14 percent are right-censored. The Pseudo- $\mathrm{R}^{2}$ is about 0.32 in the first specification and increases to 0.45 in the most comprehensive variant. The standard error is about 0.32 in all cases. A significant influence of the explanatory variables at a very high significance level is indicated by the Likelihood-Ratio Tests. Sign and magnitude of the coefficients

\footnotetext{
${ }^{16}$ Since the pioneering work of Krueger, Summers (1988), this relationship is well established in the literature.
} 
being connected with skill/ gender categories and experience rating correspond to theoretical expectations

The estimated coefficient for the urban status shows an agglomeration wage premium of about 13.5 percent in the first variant. ${ }^{17}$ This can be compared with an estimate excluding control variables, yielding a raw urban wage premium of about 15.5 percent. Recall that urban regions in our paper comprise metropolitan and intermediate core cities and their surroundings, while all other regions are classified as rural although the later still includes some urbanized districts. Compared to a more restrictive definition of rural regions, our measure of the urban wage premium would tend to understate its value. Despite this fact, the identified urban wage premium is sizable.

Using a more restrictive central city definition, Glaeser and Maré (2001) find a raw urban wage premium of roughly 33 percent for the US. Hence there is some indication that the urban/ rural wage differential in Germany is somewhat lower than in the US. ${ }^{18}$

Introducing the firm size control variable in the second variant of the specification yields two insights. First, the estimated coefficient for the large firm dummy variable in the amount of 15.6 percent reflects the often documented finding that wages are higher in larger firms. Using an approach without control variables yields a raw differential of 21 percent. This could be compared to the results of Brown et al. (1990) for the US who find a firm-size differential of 35 percent when comparing firms with more than 500 workers to those having less than 25 employees. Second, the introduction of a firm-size control variable leads to a drop in the urban wage premium of about 25 percent. Hence: one fourth of the urban wage premium can be explained by differences in the average firm-size for urban and rural regions. This result corroborates our expectation that - to some extent - the urban wage premium and the firm-size wage differential are interrelated.

The results of the third variant of the specification give evidence that the industry structure especially affects the firm-size differential. While the urban wage premium is lowered by 1.5 percentage points,

\footnotetext{
${ }^{17}$ Throughout the paper we use log percentage or log percentage points, respectively.

${ }^{18}$ According to Di Addario and Patacchini (2004), the urban wage premium in Italy is even lower and amounts to only 2-3 percent.
} 
only, the firm-size wage differential is reduced from 15.6 percent to 11.2 after controlling for the workers' industry affiliation.

Summing up the results so far, it is evident that controlling for differences in the skill/ gender composition as well as in the industry structure tends to reduce both the urban wage premium and the firm-size wage differential. However, both premia survive in the most comprehensive specification with statistically highly significant values of about 9 and 11 percent, respectively (see table 5).

\subsection{Wage level versus wage growth effect}

Having shown the existence of the premia we now turn to the explanation of their nature. Following Glaeser, Maré (2001), we might ask whether the corresponding wage differentials are the result of a wage level or a wage growth effect. If the urban wage premium is a wage growth effect due to a concentrated accumulation of human capital in cities, then it should be highest for older workers having stayed in cities for a longer time. In analogy, the same argument would be true for the firm-size wage premium. Hence, experience rating should be interrelated with urban and large firm status, respectively. Moreover, if knowledge spillovers contribute to the explanation of both premia, qualified workers should have an extra bonus for working in the city or in the large firm. In order to test these implications, we estimate the following model:

$$
\begin{aligned}
\ln w_{i} & =\alpha_{0}+\sum_{n=2}^{5} \alpha_{1, n} D-E_{\text {XPCAT }}, i+\sum_{m=2}^{3} \alpha_{2, m} D-\text { SKILLCAT }_{m, i} \\
& +\alpha_{3} D-U R B_{i}+\alpha_{4} D \text {-LFSIZE } L_{-} L_{i}+\sum_{\mathrm{k}=2}^{36} \alpha_{7, k} D-I N D_{k, i} \\
& + \text { interactions of D-EXPCAT with urban status and large firm status } \\
& + \text { interactions of } D-S K I L L C A T \text { with urban status and large firm status } \\
& + \text { gender control }+u_{i} .
\end{aligned}
$$

Table 6 shows the results. It turns out that including cross effects as described, the basic urban wage premium declines substantially and is statistically not different from zero. By contrast, the estimated large-firm premium is about 13 percent and highly significant. The estimated cross effects show that experience rating is distinctly higher in urban areas. Urban employees with a potential work experience of more than twenty years earn a 6.5 percent premium relative to those with $0-5$ years of 
experience. The bulk of shift in the urban experience premium occurs in passing from the 6-10 years of experience group to the 11-15 years group. This is in accordance with the results of Peri (1999) who finds for the US major wage gains due to urban experience for the group of 30-40 years old workers relative to the group of $20-30$ years old workers. Peri, $(1999$, p.15) states that “... the experience premium seems to mirror a process of accumulation of useful skills that is very intense early in the working life of a person, and then, following a learning curve, declines."

Interestingly, we observe a cross effect of urban status for skilled ${ }^{19}$ persons $(+2.97$ percent $)$ but no effect for the group of high skilled. While there are strong reasons for arguing that the urban wage premium is due to a wage growth effect, this is not the case for the firm-size earnings differential. Relative to the reference group of young workers, individuals in large firms with 6-15 years of experience even have a wage disadvantage of 3.5 percent. ${ }^{20}$ The result indicates both premia being generated in different ways. Although this drawback diminishes for older individuals, the results point to the fact that the large firm premium predominantly is a wage level effect. Furthermore, we detect a negative cross effect with skilled individuals (-2 percent) and a positive one with the group of highskilled ( +4 percent). This supports the view that working in agglomerations fosters the accumulation of human capital, while the bonus of working in large firms is more related to the recruitment of young high-skilled individuals who are paid very well in the beginning of their career.

Up to now we neglected the role of unobserved heterogeneity. On the one hand, the selection of our cohort eliminates a good portion of the problems being related to heterogeneity issues. On the other hand if workers in urban and rural areas still differ in their career attitudes, motivation, working behaviour and other related factors that we cannot directly observe, the estimated urban wage premium would be biased. Through the panel structure in our data, it is possible to remove the timeinvariant part of unobserved heterogeneity by employing a fixed-effects model. Using data from 1990 and biannual data from 1991, 1993, 1995 to 1997, we ran a fixed-effects version of the earnings-

\footnotetext{
${ }^{19}$ Here we differentiate between three skill categories only in order to get a breakdown of interaction effects. Different from equation (1), the gender dummy is incorporated separately.

20 This result contradicts the implications of the theory regarding seniority wages (see, for instance, Lazear (1981). According to this theory, young workers are paid below their marginal product of labour in the beginning of their career in a given firm (and above when they are older) in order to provide incentives to stay with the firm for a longer time.
} 
function approach described in section 3.1. ${ }^{21}$ In order to capture the time-variable effects of the different dimension of mobility we introduced a complete set of interaction variables. Note that the wage patterns of firm movers and regional movers allow us to identify both, the firm-size and the urban wage premium, separately.

Table 7 contains the results. The first regression depicts the effects of changing the firm, the firm-size category, the region and the type of the region. According to our estimates, firm movers get an average wage bonus relative to firm stayers of more than 7 percent in the first year after moving. Over time, this bonus slightly varies but remains in the same order of magnitude. According to our specification, the general effect of firm mobility is identified by those workers who change their workplace within the small firm-size category. Firm movers between large firms additionally have an effect which is negative in the years 1991 and 1993 (-2.7 and -2.3 percent, respectively), insignificant in 1995 and becomes positive only in 1997 ( +1.8 percent). This means that the firm related wage level effect is more pronounced for small firms. However, in large firms a wage growth effect can be identified which is absent for the small firm-size category.

Moving between firms of different size yields the expected results. Workers who move from small firms to large ones benefit from an additional wage bonus of 4.4 percent in the year after migration. Moreover, they enter a steeper wage growth path than workers in small firms. Leaving a large firm towards a small one gives negative coefficients (between -6.8 percent and -4.6 percent) indicating that this group of movers looses a part of their former firm-size wage premium. ${ }^{22}$

Turning to the regional dimension of mobility, it is evident from table 7 that only in the first year after moving the general effect of regional migration (changing firms between regions irrespective of the region type) is different from the general effect of firm mobility (changing firms within regions) $(-1.5$ percent). This effect of changing the region strongly depends on the migration patterns between more dense (i.e. high wage areas) and less dense (i.e. low wage areas) regions. For rural/ urban migrants we

\footnotetext{
${ }^{21}$ In the case of censoring, wages are imputed on the basis of Tobit estimates of the distribution parameters. More precisely, we use an approach similar to the documented one in section 3.1 (the regional and the firm size variable comprise more categories than in equation (3)) for regional movers and stayers and impute the estimated wages in case of top coding. The results of these Tobit estimates are available from the authors on request.

${ }^{22}$ Note that the effect of changing the firm is still positive for this group when the general positive effect of firm mobility is taken into account.
} 
observe significant wage gains. In the first year the wage premium relative to rural stayers is 2.8 percent, increasing monotonically during the observation period to an amount of 6.3 percent in 1997. By contrast, workers who leave dense urban areas do not experience significant losses in their earnings in the first years after their move. Only towards the end of the observation period a significantly negative effect occurs $(-3.2$ percent in 1997). This result confirms some predictions of migration models which state that a large fraction of the urban wage premium persists even after leaving a dense area. ${ }^{23}$ However, the evidence here suggests that the wage growth path for workers in rural areas is somewhat flatter than in urban areas.

To sum up, our findings indicate that behind the urban wage premium of about 8.5 percent (see table 5) we can identify a statistically significant wage level effect (2.8 percent) on the one hand as well as a statistically significant wage growth effect (up to 6.3 percent) on the other. The results suggest that unobserved time-invariant heterogeneity or workers does not play a crucial role in our cohort.

The same is true for the firm-size differential. Both the wage level effect and the wage growth effect are observable for movers from small to large firms. The losses being related to a change from a large firm to small one more or less compensate the general effects from moving in the first year after moving. Over time, the balance of the two effects becomes positive (in 1997: 7.70-4.61=3.09 percent). Hence the wage level effect is only slightly positive in this case and, again, the benefits from moving increase over time. In general, the results point to the fact that the firm-size wage level effect is more important than in the regional context.

In order to analyze the role of large firms for the development of the urban wage premium more deeply, we additionally include cross effects of regional migration and firm size mobility in the estimation approach. The results of specification 2 illustrate that more than one half of the cross effects are statistically not different from zero: neither we observe an extra bonus for those workers who change their workplace from small (large) rural firms to large (small) firms in urban areas, nor can we find an additional penalty for urban-rural movers within the large firm category. Interestingly, negative cross effects (between -5 percent and -8.4 percent) emerge for firm size movers leaving

\footnotetext{
${ }^{23}$ In these models the premium continues because of a selection bias. Mobile workers move to rural areas only if they expect high wages in the region of destination.
} 
metropolitan areas. In the first year after moving, individuals switching between both categories earn about 7-8 percent less than urban- rural migrants who change within the size categories. This supports the view that the transferability of acquired skills between types of regions is more pronounced within the size categories than between them. The effect fades away until the end of our observation period indicating that the long-time urban-rural wage growth is not affected by the change of firm-size categories.

A positive cross effect is apparent from table 7 for individuals changing their work place from large firms in rural areas to large firms in urban areas. ${ }^{24}$ The rural- urban wage level effect for this group is about 12 percent. In the years 1993 to 1997 the effect is slightly reduced to an amount of roughly 10 percent. At the same time, the wage level effect for all groups of movers into metropolitan areas vanishes, signifying that the level effect documented in specification 1 is driven by this special group of migrants. The wage growth effect has slightly decreased relative to specification 1 , but it is still highly significant.

All together, the results point out that the bulk of the urban wage premium is due to the wage growth effect. Generally, it is the urban environment with pronounced facilities of human capital accumulation which makes workers more productive. The wage level effect specifically differs for groups of movers. We conclude that the very high premium for movers to large urban firms stems from the fact that these establishments recruit the most productive workers by offering them attractive starting wages. Besides this, the results demonstrate that accumulation of skills does also take place in large firms.

\section{Conclusions}

Summing up the main results we find clear evidence for the existence of an urban wage premium in Germany. The raw premium of about 15.5 percent can be reduced by controlling for personal characteristics to approximately 13.5 percent. Introducing firm size categories in the econometric specification additionally lowers the magnitude of the urban wage premium by roughly one fourth.

\footnotetext{
${ }^{24}$ Further analysis not documented in the paper give evidence that this cross effect is especially high (more than 20 percent) for skilled movers with a potential work experience of 10 to 15 years.
} 
Hence firm-size differences between rural and urban areas explain a non negligible part of the interregional wage differential. Our findings suggest a certain relationship between agglomeration and firm-size effects. However, the urban wage premium does not completely vanish after including firm size controls. One has to conclude, therefore, that agglomeration effects work not only through firmsize effects. A further influence on the urban wage premium might stem from industry structure being specific to the region type. Controlling for these effects as well yields an urban wage premium of 8.6 percent.

When it comes to the theoretical explanation for the existence of an urban wage premium Glaeser, Maré (2001) distinguish between the following hypotheses: firstly, the more productive workers might be over-represented in cities, which would imply an ability bias between urban and rural areas. Secondly, workers with identical characteristics might be more productive in cities, hence they benefit from a wage level effect when moving from rural to urban areas. Thirdly, the environment of the city might lead to dynamic external effects rendering workers more productive over time, i.e. a wage growth effect exists. This would be the case, for example, if knowledge spillovers are more likely in cities.

The descriptive evidence shows that the share of high-skilled workers is higher in urban areas. Nevertheless, the fact that the urban wage premium survives the inclusion of skill controls rejects the presumption that region-specific differences in human capital endowment explain the observed differences in earnings. An alternative explanation of the urban/ rural wage differentials stresses unobserved heterogeneity. According to this view, the urban wage premium might accrue if - due to unobserved characteristics - urban workers exhibit a higher ability. However, after controlling for individual fixed effects we find that workers who change their work place from rural areas to cities gain from migration. Therefore, we are quite certain that the urban wage premium is not due to omitted ability bias.

Analyzing fixed-effects estimates, we do not observe wage penalties for urban-rural movers. Together with the wage gains of rural- urban movers accruing over time in the years following migration, this leads us to the conclusion that the wage growth hypothesis is the most plausible explanation. This is 
also corroborated by cross effects of urban status and experience indicating that experience rating is distinctly higher in cities.

Another main question in our paper is whether processes being responsible for urban wage growth take place within or outside large firms. To answer this question, we additionally analyze data on firm (size) movers. The firm size earnings differential of roughly 11 percent seems to be a result of both, a wage level effect and a wage growth effect. Workers being occupied in a small firm in 1990 and entering a large one thereafter, are observed to get a contemporaneous wage boost of approximately 4 percent. The benefits from working with the large firm increase over time and reach more than 8 percent by the end of our observation period.

Introducing cross effects of inter-regional and firm-size migration yields some new insights. On the one hand, the urban wage level effect can be attributed to workers being recruited by large firms. On the other hand, the urban wage growth effect can still be identified. Moreover, the cross effects demonstrate that transferability of human capital is more pronounced between firms of the same size category. All together, the results lead us to the conclusion that large firms play a crucial role for explaining the higher productivity in urban areas. Nevertheless, there is overwhelming evidence that wage growth in urban areas is not tied to the firm level. Hence our findings confirm the view that externalities are operating in the urban environment and not only within the firms.

\section{References}

Adamson, D.W., Clark, D.E., Partridge, M.D. (2004) Do urban agglomeration effects and household amenities have a skill bias? Journal of Regional Science 44 (2): 201-224.

Bender, S., Haas, A. (2002): Die IAB-Beschäftigtenstichprobe, in: Kleinhenz, G. (Hrsg.), IABKompendium Arbeitsmarkt- und Berufsforschung, Nürnberg, 3-12.

Brown, C., Medoff, J. (1997) Firm age and wages, mimeo, University of Michigan.

Brown, C., Hamilton, J., Medoff, J. (1990) Employers large and small, Cambridge: Harvard University Press, 1990.

Ciccone, A. (2002) Agglomeration effects in Europe, European Economic Review 46: 213-227. 
Ciccone, A., Hall, R.E. (1996) Productivity and the density of economic activity, American Economic Review 86 (1): 54-70.

Combes, P., Duranton, G. Gobillon, L. (2003) Spatial wage disparities : Sorting matters ! http://www.enpc.fr/ceras/labo/LLM45.pdf

Di Addario, S., Patacchini, E. (2004) Is there an urban wage premium in Italy? http://www.iue.it/ECO/Conferences/BrucchiLuchinoConference/Papers/Patacchini.pdf

Diamond, C.A., Simon C.J. (1990) Industrial specialization and the returns to labor, Journal of Labor Economics 8(2): 175-201.

Fujita M., Krugman, P.R., Venables, A.J. (1999) The spatial economy: Cities, regions and international trade, MIT Press, Cambridge (Mass.).

Glaeser E.L., Maré, D.C. (2001) Cities and skills, Journal of Labor Economics 19: 316-342.

Gould, E.D. (2005) Cities, workers, and wages: A structural analysis of the urban wage premium, http://micro5.mscc.huji.ac.il/ economics/facultye/gould/revised_city_february_2005.pdf

Haas, A., Moeller, J. (2003) The agglomeration wage differential reconsidered - an investigation using German micro data 1983-1997; In: Broecker, J., Dohse, D., Soltwedel, R. (Eds.), Innovation clusters and interregional competition, Berlin Heidelberg, New York: Springer.

Harris, T.F., Ioannides, Y.M. (2000) Productivity and metropolitan density, Discussion Papers Series 0016, Department of Economics, Tufts University.

Harris, J., Todaro, M. (1970) Migration, unemployment and development: a two-sector analyses, American Economic Review 60: 126-142.

Henderson, J.V. (1986) Efficiency of resource usage and city size, Journal of Urban Economics 19: 47-70.

Hunt, J. (2004) Are migrants more skilled than non-migrants? Repeat, return and same-employer migrants", Canadian Journal of Economics 37(4): 830-849.

Krueger, A. B., Summers, L. H. (1988) Efficiency wages and the inter-industry wage structure, Econometrica 56: 259-294.

Lazear, E.P. (1981) Agency, earnings profiles, productivity, and hours restrictions, American Economic Review 71 (4): 606-620.

Lucas, R.E. JR. (2001) Externalities and cities, Review of Economic Dynamics 4 (2): 245-274.

Marshall, A. (1890) Principles of economics, London: Macmillan and Co., Ltd., 1920, Eight Edition.

Mincer, J. (1974) Schooling, experience and earnings, New York, National Bureau of Economic Research.

Moomaw, R.L. (1981) Productivity and city size: a critique of the evidence, Quarterly Journal of Economics 96 (4): 675-688.

Moomaw, R.L. (1985) Firm location and city size: reduced productivity advantages as a factor in the decline of manufacturing in urban areas, Journal of Urban Economics 17 (1): 73-89.

Moretti, E. (2004) Human capital externalities in cities, in: Henderson, J.V., Thisse, J.F., (eds.) Handbook of Regional and Urban Economics, Amsterdam and New York: North Holland. 
Oi, W., Idson, J.L. (1999) Firm Size and Wages, in: Ashenfelter, O., Card, D. (eds.) Handbook of Labor Economics, Elsevier, Amsterdam: 2165-2214.

Peri, G. (1999) Local human capital externalities: an overlapping generation model and some evidence on experience premia, CESifo Working Paper No. 219.

Peri, G. (2001) Young People, Skills and Cities, CESifo Working Paper No. 610.

Rauch, J.E. (1993) Productivity gains from geographic concentration of human capital: Evidence from the cities, Journal of Urban Economics 34 (3): 380-400.

Rosenthal, S.S., Strange,W.C. (2005) The attenuation of human capital spillovers: A Manhattan skyline approach, http://www.aeaweb.org/annual_mtg_papers/2006/0106_1430_1603.pdf

Segal, D. (1976) Are there Returns to Scale in City Size? Review of Economics and Statistics 58: 339350 .

Sveikauskas, L.A. (1975) The productivity of cities, Quarterly Journal of Economics 89: 393-413

Tabuchi, T., Yoshida, A. (2000) Separating agglomeration economies in consumption and production, Journal of Urban Economics 48: 70-84.

Troske, K.R. (1999) Evidence on the employer size- wage premium from worker- establishment matched data, Review of Economics and Statistics 81 (1): 15-26.

Wheaton, W.C., Lewis, M.J. (2002) Urban wages and labor market agglomerations, Journal of Urban Economics 51: 542-562.

Wheeler, C.H. (2001) Search, sorting and urban agglomeration, Jounal of Labor Economics 19:879899.

Wooldridge, J.M. (2002) Econometric analysis of cross section and panel data, Cambridge (MA) and London: The MIT Press. 


\section{Table A1: Regional Classification Scheme based on BBR-Classification}

\begin{tabular}{|c|c|c|c|}
\hline Structural region type & $\begin{array}{l}\text { District type (BBR- } \\
\text { Classification) }\end{array}$ & $\begin{array}{l}\text { Region types (RT) } \\
\text { used in the paper }\end{array}$ & Description of region type (BBR) \\
\hline \multirow{4}{*}{$\begin{array}{l}\text { Regions with large } \\
\text { agglomerations }\end{array}$} & BBR1 & urban & Core cities \\
\hline & BBR2 & urban & $\begin{array}{l}\text { Highly urbanized districts in regions } \\
\text { with large agglomerations }\end{array}$ \\
\hline & BBR3 & rural & $\begin{array}{l}\text { Urbanized districts in regions with } \\
\text { large agglomerations }\end{array}$ \\
\hline & BBR4 & rural & $\begin{array}{l}\text { Rural districts in regions with large } \\
\text { agglomerations }\end{array}$ \\
\hline \multirow{3}{*}{$\begin{array}{l}\text { Regions with features of } \\
\text { conurbation }\end{array}$} & BBR5 & urban & $\begin{array}{l}\text { Central cities in regions with } \\
\text { intermediate agglomerations }\end{array}$ \\
\hline & BBR 6 & rural & $\begin{array}{l}\text { Urbanized districts in regions with } \\
\text { intermediate agglomerations }\end{array}$ \\
\hline & BBR 7 & rural & $\begin{array}{l}\text { Rural districts in regions with } \\
\text { intermediate agglomerations }\end{array}$ \\
\hline \multirow{2}{*}{$\begin{array}{l}\text { Regions of rural } \\
\text { character }\end{array}$} & BBR8 & rural & Urbanized districts in rural regions \\
\hline & BBR9 & rural & Rural districts in rural regions \\
\hline
\end{tabular}

Table A2: Selection of Data (1990/ 91/ 93/ 95/ 97)

\begin{tabular}{|c|c|}
\hline & number of cases \\
\hline total number of individual observations & $1,317,227$ \\
\hline old laender only & $1,131,290$ \\
\hline multiple employed workers excluded & $1,117,831$ \\
\hline with valid earnings information & $1,083,153$ \\
\hline workers in an apprenticeship, volunteers, family workers excluded & $1,019,969$ \\
\hline with valid information about experience and place of work & 942,823 \\
\hline part-timer workers excluded & 826,913 \\
\hline Observations used in our sample & 826,913 \\
\hline
\end{tabular}


Table 1: Absolute Number and Share of Movers and Stayers in the Cohort (1991-1997)

\begin{tabular}{|c|c|c|}
\hline total & 58,112 & \\
\hline $\begin{array}{l}\text { therof } \\
\text { firm stayers } \\
\text { percent of total } \\
\text { firm movers } \\
\text { percent of total } \\
\text { thereof movers } \\
\text { between small firms } \\
\text { from small to large firm } \\
\text { from large to small firm } \\
\text { between large firms }\end{array}$ & $\begin{array}{c}54,446 \\
93.7 \\
3,666 \\
6.3\end{array}$ & $\begin{array}{c}2,353 \\
555 \\
358 \\
400 \\
\end{array}$ \\
\hline $\begin{array}{l}\text { regional stayers } \\
\text { percent of total } \\
\text { regional movers } \\
\text { percent of total } \\
\text { thereof movers } \\
\text { within urban areas } \\
\text { from urban to rural areas } \\
\text { from rural to urban areas } \\
\text { within rural areas }\end{array}$ & $\begin{array}{c}56,634 \\
97.5 \\
1,478 \\
2.5\end{array}$ & $\begin{array}{l}615 \\
251 \\
268 \\
344\end{array}$ \\
\hline
\end{tabular}

Source: Own calculations using IAB-REG data.

Table 2: Absolute Number and Share of Workers by Firm Size Category and Region Type (1990)

\begin{tabular}{|c|c|c|c|c|}
\hline & $\begin{array}{c}\text { U } \\
\text { Number of } \\
\text { observations }\end{array}$ & Share in $\%$ & $\begin{array}{c}\mathrm{R} \\
\text { Number of } \\
\text { observations }\end{array}$ & Share in $\%$ \\
\hline small firm size & 18,941 & 56.22 & 18,886 & 77.33 \\
\hline large firm size & 14,748 & 43.78 & 5,537 & 22.67 \\
\hline total & 33,689 & 100 & 24,423 & 100 \\
\hline
\end{tabular}

Source: Own calculations using IAB-REG data. 
Table 3: Skill and Gender Composition of the Workforce by Region Type (1990)

\begin{tabular}{|c|c|c|c|c|c|}
\hline & \multicolumn{2}{|c|}{ Rural areas } & \multicolumn{2}{|c|}{ Urban areas } & \multirow{2}{*}{$\begin{array}{l}\text { Difference } \\
\text { urban vs } \\
\text { rural in } \%\end{array}$} \\
\hline & $\begin{array}{c}\text { Number of } \\
\text { observations }\end{array}$ & Share in \% & $\begin{array}{c}\text { Number of } \\
\text { observations }\end{array}$ & Share in $\%$ & \\
\hline $\begin{array}{l}\text { low-skilled } \\
\text { skilled } \\
\text { high-skilled } \\
\text { total }\end{array}$ & $\begin{array}{c}4,628 \\
18,855 \\
940 \\
24,423 \\
\end{array}$ & $\begin{array}{c}18.95 \\
77.20 \\
3.85 \\
100 \\
\end{array}$ & $\begin{array}{c}\text { all } \\
6,067 \\
24,748 \\
2,874 \\
33,689 \\
\end{array}$ & $\begin{array}{c}18.01 \\
73.46 \\
8.53 \\
100 \\
\end{array}$ & $\begin{array}{r}-0.94 \\
-3.74 \\
4.68\end{array}$ \\
\hline $\begin{array}{l}\text { low-skilled } \\
\text { skilled } \\
\text { high-skilled } \\
\text { total }\end{array}$ & $\begin{array}{c}2,981 \\
14,363 \\
833 \\
18,177 \\
\end{array}$ & $\begin{array}{c}16.40 \\
79.02 \\
4.58 \\
100 \\
\end{array}$ & $\begin{array}{c}\text { males } \\
4,085 \\
17,858 \\
2,509 \\
24,452 \\
\end{array}$ & $\begin{array}{c}16.71 \\
73.03 \\
10.26 \\
100 \\
\end{array}$ & $\begin{array}{r}0.31 \\
-5.98 \\
5.68\end{array}$ \\
\hline $\begin{array}{l}\text { low-skilled } \\
\text { skilled } \\
\text { high-skilled } \\
\text { total }\end{array}$ & $\begin{array}{c}1,647 \\
4,492 \\
107 \\
6,246 \\
\end{array}$ & $\begin{array}{c}26.37 \\
71.92 \\
1.71 \\
100 \\
\end{array}$ & $\begin{array}{c}\text { females } \\
1,982 \\
6,890 \\
365 \\
9,237\end{array}$ & $\begin{array}{c}21.46 \\
74.59 \\
3.95 \\
100\end{array}$ & $\begin{array}{r}-4.91 \\
2.67 \\
2.24\end{array}$ \\
\hline
\end{tabular}

Source: Own calculations using IAB-REG data. 
Table 4: Skill and Gender Composition of the Workforce by Firm Size (1990)

\begin{tabular}{|c|c|c|c|c|c|}
\hline & \multicolumn{2}{|c|}{ Small firms } & \multicolumn{2}{|c|}{ Large firms } & \multirow{2}{*}{$\begin{array}{c}\text { Difference } \\
\text { Large vs } \\
\text { small in } \%\end{array}$} \\
\hline & $\begin{array}{c}\text { Number of } \\
\text { observations }\end{array}$ & Share in \% & $\begin{array}{c}\text { Number of } \\
\text { observations }\end{array}$ & Share in $\%$ & \\
\hline \multirow{5}{*}{$\begin{array}{l}\text { low-skilled } \\
\text { skilled } \\
\text { high-skilled } \\
\text { total }\end{array}$} & \multicolumn{5}{|c|}{ all } \\
\hline & 6,395 & 16.91 & 4,300 & 21.20 & 4.29 \\
\hline & 29,651 & 78.39 & 13,952 & 68.78 & -9.61 \\
\hline & 1,781 & 4.71 & 2,033 & 10.02 & 5.31 \\
\hline & 37,827 & 100 & 20,285 & 100 & \\
\hline \multirow{5}{*}{$\begin{array}{l}\text { low-skilled } \\
\text { skilled } \\
\text { high-skilled } \\
\text { total }\end{array}$} & \multicolumn{5}{|c|}{ males } \\
\hline & 4,074 & 15.29 & 2,992 & 18.72 & 3.43 \\
\hline & 21,084 & 79.14 & 11,137 & 69.67 & -9.47 \\
\hline & 1,485 & 5.57 & 1,857 & 11.62 & 6.04 \\
\hline & 26,643 & 100 & 15,986 & 100 & \\
\hline & \multicolumn{5}{|c|}{ females } \\
\hline low-skilled & 2,321 & 20.75 & 1,308 & 30.43 & 9.67 \\
\hline skilled & 8,567 & 76.60 & 2,815 & 65.48 & -11.12 \\
\hline high-skilled & 296 & 2.65 & 176 & 4.09 & 1.45 \\
\hline total & 11,184 & 100 & 4,299 & 100 & \\
\hline
\end{tabular}

Source: Own calculations using IAB-REG data. 
Table 5: Urban Wage Premium and Firm Size Wage Premium (1997)

\begin{tabular}{|c|c|c|c|c|c|c|}
\hline \multirow[b]{3}{*}{ Variable } & \multicolumn{6}{|c|}{ Specification } \\
\hline & \multicolumn{2}{|c|}{ Variant (I) } & \multicolumn{2}{|c|}{ Variant (II) } & \multicolumn{2}{|c|}{ Variant (III) } \\
\hline & Coef. & $\mathrm{t}$-Statistics & Coef. & $\mathrm{t}$-Statistics & Coef. & t-Statistics \\
\hline Low-skilled male (ref.) & & & & & & \\
\hline Skilled male & 0.129 & 4.19 & 0.115 & 3.82 & 0.080 & 2.81 \\
\hline High-skilled male & 0.691 & 21.78 & 0.656 & 21.19 & 0.596 & 20.21 \\
\hline Low-skilled female & 0.052 & 2.37 & 0.050 & 2.33 & 0.011 & 0.51 \\
\hline Skilled female & 0.121 & 3.24 & 0.113 & 3.1 & 0.053 & 1.54 \\
\hline High-skilled female & 0.571 & 14.09 & 0.551 & 13.95 & 0.487 & 12.94 \\
\hline Experience & 0.023 & 10.38 & 0.020 & 9.19 & 0.017 & 8.3 \\
\hline Experience squared & -0.037 & -9.73 & -0.031 & -8.32 & -0.026 & -7.52 \\
\hline Interaction exp. / fem. & -0.018 & -10.02 & -0.016 & -9.61 & -0.014 & -8.79 \\
\hline Interaction exp. squared / fem. & 0.023 & 6.99 & 0.021 & 6.43 & 0.018 & 5.98 \\
\hline Interaction exp. /qual. & 0.005 & 1.98 & 0.006 & 2.74 & 0.006 & 3 \\
\hline Interaction exp. squared/qual. & -0.007 & -1.68 & -0.009 & -2.23 & -0.008 & -2.25 \\
\hline Urban status & 0.135 & 47.84 & 0.101 & 35.84 & 0.086 & 31.12 \\
\hline Firm size: large & - & & 0.156 & 52.62 & 0.112 & 35.37 \\
\hline Constant & 9.261 & 310.9 & 9.247 & 318.44 & 9.037 & 286.1 \\
\hline industry controls & no & & no & & yes & \\
\hline \multicolumn{7}{|c|}{ Test statistics } \\
\hline$N$ & 58,112 & & 58,112 & & 58,112 & \\
\hline (thereof censored) & 8,299 & & 8,299 & & 8,299 & \\
\hline Pseudo $\mathrm{R}^{2}$ & 0.322 & & 0.363 & & 0.449 & \\
\hline LR [chi2( 12$) ;(13) ;(48)]$ & 21165.18 & & 23876.07 & & 29516.2 & \\
\hline s.e. & 0.328 & & 0.320 & & 0.304 & \\
\hline
\end{tabular}

Notes: Estimation method is Tobit; all coefficients significant at least at the 5 percent level are in bold; all coefficients related to the experience squared variable are multiplied by 100 .

Source: Authors' own calculations using IAB-REG data. 
Table 6: Interaction of Urban Status / Large Firm Status and Human Capital Variables (1991)

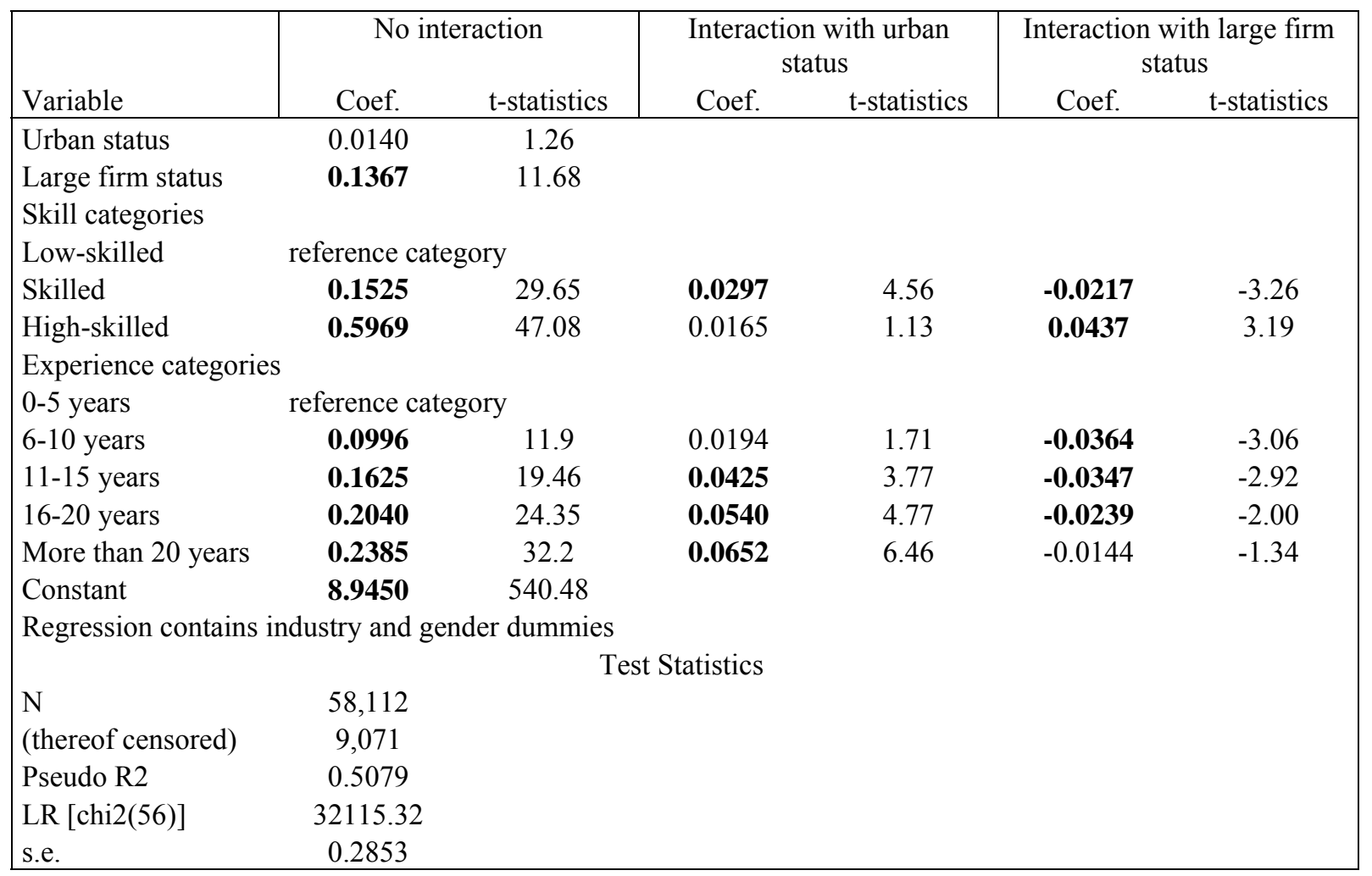

Notes: Estimation method is Tobit; all coefficients significant at least at the 5 percent level are in bold; all coefficients related to the experience squared variable are multiplied by 100 .

Source: Authors' own calculations using IAB-REG data. 
Table 7: Results of the Fixed Effect Estimates (Using Biannual Data 1991 to 1997)

\begin{tabular}{|lc|cc|cc|}
\hline \multirow{2}{*}{ Variable } & & \multicolumn{2}{|c|}{ Specification 1 } & \multicolumn{2}{c|}{ Specification 2} \\
& & Coef. & t-statistics & Coef. & t-statistics \\
\hline Regional mobility & 1991 & $\mathbf{- 0 . 0 1 5 2}$ & -2.70 & $\mathbf{- 0 . 0 1 5 3}$ & -2.72 \\
Rural- urban mobility & 1993 & -0.0053 & -0.94 & -0.0055 & -0.97 \\
& 1995 & -0.0020 & -0.35 & -0.0022 & -0.39 \\
& 1997 & -0.0006 & -0.11 & -0.0007 & -0.12 \\
& 1991 & $\mathbf{0 . 0 2 8 4}$ & 2.81 & 0.0098 & 0.75 \\
Urban- rural mobility & 1993 & $\mathbf{0 . 0 4 5 6}$ & 4.52 & $\mathbf{0 . 0 3 5 2}$ & 2.71 \\
& 1995 & $\mathbf{0 . 0 4 6 7}$ & 4.62 & $\mathbf{0 . 0 4 1 3}$ & 3.18 \\
& 1997 & $\mathbf{0 . 0 6 3 3}$ & 6.27 & $\mathbf{0 . 0 5 4 6}$ & 4.21 \\
Firm mobility & 1991 & -0.0139 & -1.34 & -0.0010 & -0.08 \\
& 1993 & -0.0104 & -1.01 & -0.0030 & -0.24 \\
& 1995 & -0.0198 & -1.92 & -0.0072 & -0.57 \\
Large firm to small firm & 1997 & $\mathbf{- 0 . 0 3 2 1}$ & -3.11 & $\mathbf{- 0 . 0 2 6 8}$ & -2.14 \\
& 1991 & $\mathbf{0 . 0 7 6 3}$ & 21.20 & $\mathbf{0 . 0 7 6 7}$ & 20.92 \\
& 1993 & $\mathbf{0 . 0 8 7 2}$ & 24.20 & $\mathbf{0 . 0 8 7 4}$ & 23.83 \\
& 1995 & $\mathbf{0 . 0 8 4 3}$ & 23.38 & $\mathbf{0 . 0 8 3 9}$ & 22.84 \\
Small firm to large firm & 1997 & $\mathbf{0 . 0 7 7 0}$ & 21.32 & $\mathbf{0 . 0 7 7 2}$ & 21.00 \\
& 1991 & $\mathbf{- 0 . 0 6 8 5}$ & -8.26 & $\mathbf{- 0 . 0 6 0 4}$ & -6.75 \\
& 1993 & $\mathbf{- 0 . 0 6 1 3}$ & -7.39 & $\mathbf{- 0 . 0 5 2 7}$ & -5.89 \\
& 1995 & $\mathbf{- 0 . 0 5 5 6}$ & -6.71 & $\mathbf{- 0 . 0 4 7 2}$ & -5.27 \\
Large firm to large firm & 1997 & $\mathbf{- 0 . 0 4 6 1}$ & -5.56 & $\mathbf{- 0 . 0 4 1 2}$ & -4.60 \\
& 1991 & $\mathbf{0 . 0 4 4 1}$ & 6.33 & $\mathbf{0 . 0 4 4 3}$ & 5.83 \\
& 1993 & $\mathbf{0 . 0 6 5 8}$ & 9.43 & $\mathbf{0 . 0 6 6 5}$ & 8.74 \\
& 1995 & $\mathbf{0 . 0 7 3 0}$ & 10.47 & $\mathbf{0 . 0 7 7 0}$ & 10.13 \\
& 1997 & $\mathbf{0 . 0 8 3 7}$ & 12.00 & $\mathbf{0 . 0 8 6 0}$ & 11.30 \\
& 1991 & $\mathbf{- 0 . 0 2 7 0}$ & -3.42 & $\mathbf{- 0 . 0 3 7 3}$ & -4.40 \\
& 1993 & $\mathbf{- 0 . 0 2 2 9}$ & -2.90 & $\mathbf{- 0 . 0 3 3 0}$ & -3.89 \\
& 1995 & -0.0055 & -0.69 & -0.0138 & -1.63 \\
& 1997 & $\mathbf{0 . 0 1 7 8}$ & 2.26 & 0.0085 & 1.00 \\
\hline
\end{tabular}


Table 7 (continued)

\begin{tabular}{|c|c|c|c|c|c|}
\hline \multirow{2}{*}{\multicolumn{2}{|c|}{ Variable }} & \multicolumn{2}{|c|}{ Specification 1} & \multicolumn{2}{|c|}{ Specification 2} \\
\hline & & Coef. & t-statistics & Coef. & t-statistics \\
\hline \multirow[t]{4}{*}{ Interaction rural-urban. small-large } & 1991 & - & & 0.0340 & 1.59 \\
\hline & 1993 & - & & 0.0159 & 0.74 \\
\hline & 1995 & - & & -0.0020 & -0.09 \\
\hline & 1997 & - & & 0.0024 & 0.11 \\
\hline \multirow[t]{3}{*}{ Interaction rural-urban. large-small } & 1991 & - & & -0.0384 & -0.95 \\
\hline & 1993 & - & & -0.0530 & -1.31 \\
\hline & 1995 & - & & -0.0524 & -1.30 \\
\hline \multirow{5}{*}{ Interaction rural-urban. large-large } & 1997 & - & & -0.0158 & -0.39 \\
\hline & 1991 & - & & 0.1198 & 3.63 \\
\hline & 1993 & - & & 0.0986 & 2.99 \\
\hline & 1995 & - & & 0.0968 & 2.93 \\
\hline & 1997 & - & & 0.0976 & 2.96 \\
\hline \multirow[t]{4}{*}{ Interaction urban-rural. small-large } & 1991 & - & & -0.0842 & -2.44 \\
\hline & 1993 & - & & -0.0496 & -1.44 \\
\hline & 1995 & - & & -0.0756 & -2.19 \\
\hline & 1997 & - & & -0.0438 & -1.27 \\
\hline \multirow[t]{4}{*}{ Interaction urban-rural. large-small } & 1991 & - & & -0.0702 & -2.53 \\
\hline & 1993 & - & & -0.0655 & -2.36 \\
\hline & 1995 & - & & -0.0658 & -2.38 \\
\hline & 1997 & - & & -0.0449 & -1.62 \\
\hline \multirow{4}{*}{ Interaction urban-rural. large-large } & 1991 & - & & 0.0377 & 1.25 \\
\hline & 1993 & - & & 0.0525 & 1.75 \\
\hline & 1995 & - & & 0.0295 & 0.98 \\
\hline & 1997 & - & & 0.0425 & 1.41 \\
\hline \multicolumn{2}{|l|}{ Constant } & 10.0603 & 666.3 & 10.0603 & 666.3 \\
\hline \multicolumn{6}{|c|}{ Test statistics } \\
\hline \multirow{2}{*}{\multicolumn{2}{|c|}{$\begin{array}{l}N \text { (groups) } \\
\mathrm{F}(58111,232380) ; \mathrm{F}(58111,232356)\end{array}$}} & 58112 & & \multirow{2}{*}{\multicolumn{2}{|c|}{$\begin{array}{c}58112 \\
53.82\end{array}$}} \\
\hline & & 53.82 & & & \\
\hline
\end{tabular}

Notes: All coefficients significant at least at the 5 percent level are in bold. In the case of censoring, wages are calculated in the framework of an imputation procedure using Tobit estimation method.

Source: Authors' own calculations using IAB-REG data. 